\title{
Trophic ecology of range-expanding round sardinella and resident sympatric species in the NW Mediterranean
}

\author{
Marta Albo-Puigserver ${ }^{1, *}$, Diego Borme ${ }^{2}$, Marta Coll ${ }^{1}$, Valentina Tirelli ${ }^{2}$, \\ Isabel Palomera ${ }^{1}$, Joan Navarro ${ }^{1}$ \\ ${ }^{1}$ Institut de Ciències del Mar - CSIC, Barcelona 08003, Spain \\ ${ }^{2}$ Istituto Nazionale di Oceanografia e di Geofisica Sperimentale (OGS), Trieste 34151, Italy
}

\begin{abstract}
The recent northward expansion of the round sardinella Sardinella aurita in the Mediterranean Sea has been documented as a consequence of rising sea temperature. At the same time, declines in sardine and anchovy biomass have been observed in the NW Mediterranean Sea, necessitating an assessment of whether the expansion of round sardinella may affect sardine and anchovy populations. Here, we combined stomach content and isotopic analyses to describe the trophic habits of round sardinella in the NW Mediterranean Sea and its trophic relationships with 2 sympatric small pelagic fish, European anchovy Engraulis encrasicolus and European pilchard Sardina pilchardus. Results revealed changes in the diet of round sardinella during the year. In summer, the most important prey were copepods (Acartia spp.) and cladocerans (Penilia avirostris). During winter, the diet was composed mainly of copepods and tunicates (mainly appendicularians), but microplankton was also numerically important in adult diets. In contrast to previous studies, during spring, round sardinella principally fed on salps (Thaliacea). To our knowledge, this is the first time that salps have been identified as an important prey for round sardinella. When compared to coexisting small pelagic fish, we found that round sardinella adults had a different trophic niche than anchovy and sardine. In contrast, round sardinella juveniles partially overlapped the trophic niche with the juveniles of the other 2 species. Therefore, the range expansion of round sardinella probably would not affect sardine and anchovy populations. Only in a situation of food limitation could juveniles of round sardinella compete with and affect both sympatric species. Our results provide new insights into the ecological role of this range-expanding species in the NW Mediterranean Sea, and highlight the importance of gelatinous zooplankton as prey.
\end{abstract}

KEY WORDS: Gelatinous zooplankton · Sardine · Anchovy · Small pelagic fish · Trophic segregation · Stable isotopes $\cdot$ Stomach contents $\cdot$ Trophic pathways

\section{INTRODUCTION}

Climate change has biological effects on physiological, phenotypical and distributional patterns of marine species that can affect biological interactions (Hughes \& Grand 2000). The expansion of certain species outside of their native range may have important effects on ecosystems (Sorte et al. 2010, Last et al. 2011). Although shifts or expansions in the geographic distribution of non-native or range-expanding species (i.e. species that enter a habitat in which they do not currently exist) have been well documented, the potential ecological and socioeconomic consequences of these expansions are not well understood, due to the amount of ecological information required at different levels of organization (species, community and ecosystem; Madin et al. 2012). The basic knowledge of how these species use trophic resources is crucial information to evaluate their impact on the new community (Sunday et al. 2015). Overall, 2 main trophic pathways have been suggested to explain resource acquisition by non- 
native or range-expanding species: (1) they may exploit novel niche opportunities that most native species are unable to use (opportunism hypothesis), or (2) they may exploit the resources used by native species, displacing the native species from their preferred niches (competition hypothesis) (Tilman 2004, San Sebastián et al. 2015).

Traditionally, the round sardinella Sardinella aurita has been widely distributed in the southern part of the Mediterranean Sea and subtropical waters of the Atlantic Ocean, due to its preference for spawning in warm waters (Ben-Tuvia 1960, Sabatés et al. 2006, 2009). The northward expansion of round sardinella in the Mediterranean Sea has been documented over the last decade as a consequence of the increase in sea surface temperatures associated with global warming (Sabatés et al. 2006, Tsikliras 2008). Similarly, in other areas of the Atlantic Ocean such as the coast of Mauritania, Morocco and the Canary Archipelago, higher abundances of this species have been recorded in recent years due to high surface temperatures (Zeeberg et al. 2008, Alheit et al. 2014).

As a consequence of the high feeding intensity and the wide plasticity and adaptability to environmental fluctuations and food availability of round sardinella (Cury \& Fontana 1988, Tsikliras et al. 2005, Morote et al. 2008, 2010), this species may have an impact via trophic competition or direct predation on closely- related Clupeiformes, such as the European pilchard Sardina pilchardus (hereafter referred to as sardine) and the European anchovy Engraulis encrasicolus (hereafter referred to as anchovy), 2 well-established small pelagic fish species in the northern Mediterranean Sea. The 3 species have been described as planktivorous fish that mainly prey on copepods, cladocerans and diatoms (Table 1). Previous trophic studies conducted in the eastern Mediterranean Sea revealed that round sardinella, sardine and anchovy exploit similar food resources throughout the year but with differences between seasons (e.g. for round sardinella, copepods were described as the main prey in fall, while for sardine, copepods were the main prey in winter; Karachle \& Stergiou 2014). On the contrary, an isotopic niche analysis of these 3 clupeids in the NW Mediterranean Sea found different trophic niches for adult stages (Albo-Puigserver et al. 2016). Although the trophic habits of sardine and anchovy in the western Mediterranean Sea have been well studied (e.g. Costalago et al. 2012, Le Bourg et al. 2015, Brosset et al. 2016, and see references in Table 1), to our knowledge, only 1 study conducted in this area found high dietary overlap between round sardinella and anchovy at larval stages (Morote et al. 2008). No information on the diet composition of juveniles and adults of round sardinella in the western Mediterranean is available.

Table 1. Summary of the available published data on diet, including results of the present study (grey shading), based on stomach content analysis and the main prey groups reported for round sardinella Sardinella aurita, anchovy Engraulis encrasicolus and sardine Sardina pilchardus in the NW Mediterranean Sea. Seasons with available information are indicated with an 'x' (1: winter; 2: spring; 3: summer; 4: fall)

\begin{tabular}{|c|c|c|c|c|c|c|}
\hline \multirow{2}{*}{$\begin{array}{l}\text { Life } \\
\text { stage }\end{array}$} & \multirow[t]{2}{*}{ Main prey groups } & \multicolumn{4}{|c|}{ Season } & \multirow[t]{2}{*}{ References } \\
\hline & & 1 & 2 & 3 & 4 & \\
\hline \multicolumn{7}{|c|}{ Round sardinella } \\
\hline Larva & Copepod nauplii and postnauplii, cladocerans & & $\mathrm{x}$ & & & Morote et al. (2008), present study \\
\hline Juvenile & Copepods, cladocerans, appendicularians, salps & $\mathrm{x}$ & $\mathrm{x}$ & $\mathrm{x}$ & & \\
\hline Adult & $\begin{array}{l}\text { Copepods, cladocerans, appendicularians, salps, } \\
\text { diatoms, tintinnids }\end{array}$ & $\mathrm{x}$ & $\mathrm{x}$ & $\mathrm{x}$ & & \\
\hline \multicolumn{7}{|l|}{ Anchovy } \\
\hline Larva & $\begin{array}{l}\text { Copepod eggs, nauplii and postnauplii, } \\
\text { cladocerans }\end{array}$ & & $\mathrm{x}$ & $\mathrm{x}$ & & $\begin{array}{l}\text { Costalago et al. (2014), Le Bourg et al. } \\
\text { (2015), Morote et al. (2010), Plounevez \& }\end{array}$ \\
\hline Juvenile & Copepods, cladocerans, appendicularians & $\mathrm{x}$ & & $\mathrm{x}$ & $\mathrm{x}$ & Champalbert (2000), Intxausti et al. (2017), \\
\hline Adult & $\begin{array}{l}\text { Copepods, cladocerans, decapods, } \\
\text { appendicularians }\end{array}$ & & $\mathrm{x}$ & $\mathrm{x}$ & & $\begin{array}{l}\text { Tudela \& Palomera (1997), Brosset et al. } \\
\text { (2016) }\end{array}$ \\
\hline \multicolumn{7}{|l|}{ Sardine } \\
\hline Larva & Tintinnids, copepod nauplii and postnauplii & & & & $\mathrm{x}$ & Costalago et al. (2014), Costalago \& \\
\hline Juvenile & $\begin{array}{l}\text { Copepods, cladocerans, appendicularians, } \\
\text { mysids, diatoms }\end{array}$ & $\mathrm{x}$ & $\mathrm{x}$ & $\mathrm{x}$ & $\mathrm{x}$ & $\begin{array}{l}\text { Palomera (2014), Le Bourg et al. (2015), } \\
\text { Morote et al. (2010), Brosset et al. (2016) }\end{array}$ \\
\hline Adult & $\begin{array}{l}\text { Copepods, cladocerans, appendicularians, } \\
\text { diatoms }\end{array}$ & $\mathrm{x}$ & & $\mathrm{x}$ & & \\
\hline
\end{tabular}


This impairs our current capability to assess the ecological consequences that the northward expansion of this species has on other pelagic species.

In addition to the northward expansion of round sardinella, in recent decades important declines in biomass, landings and body condition of sardine and anchovy have been observed in the NW Mediterranean Sea (Van Beveren et al. 2014, Brosset et al. 2017). The stocks of both species are overfished in this area (Coll \& Bellido 2019). In contrast, round sardinella landings have increased, with large fluctuations due to its low commercial value (Palomera et al. 2007, Coll et al. 2019). At present, the potential factors controlling the population of small pelagic fish in the NW Mediterranean are still unclear and there is an urgent need to understand the mechanisms that are driving these fluctuations and to assess whether the expansion of round sardinella affects sardine and anchovy populations (competition hypothesis) and the whole pelagic marine food web (Coll et al. 2019). The 3 species mainly occur from the coastal area to the edge of the continental shelf. Sardine is found in waters up to $200 \mathrm{~m}$ depth, although it is more common in shallower areas, and anchovy is distributed in a larger area from the coast to off-shore waters, to areas where the maximal depth is around $400 \mathrm{~m}$ (Palomera et al. 2007). Round sardinella has a preference for depths of $40-60 \mathrm{~m}$ (Zgozi et al. 2018), and spawning of round sardinella takes place in shallower waters than anchovy, although both species spatially overlap at the larval stages (Sabatés et al. 2008, Schismenou et al. 2008).

Accordingly, the aim of the present study was to investigate the diet of round sardinella on a seasonal basis, and compare it with trophic information on sardine and anchovy from the same area, through complementary methodologies: stomach content analysis and stable isotope analysis $\left(\delta^{15} \mathrm{~N}\right.$ and $\delta^{13} \mathrm{C}$ values). Isotopic information provides a long-term, integrated measure of the assimilated food to explore the trophic niche relationships between the 3 sympatric species on a wide temporal scale, while stomach content analysis provides more detail about the prey (Boecklen et al. 2011). Although outcomes of stomach content and isotopic analysis need to be interpreted with caution (Nielsen et al. 2018), their combination is very useful to better understand the trophic ecology of organisms at different time scales and resolutions, and has previously been successfully used in the study of small pelagic fishes (e.g. Costalago et al. 2014, Le Bourg et al. 2015).

\section{MATERIALS AND METHODS}

\subsection{Study area and sampling procedure}

The study area was located on the continental shelf of the Ebro River Delta (NW Mediterranean Sea; Fig. 1). This area is an important fishing ground and spawning area for small pelagic fishes and has been identified as a priority area of conservation (Palomera et al. 2007, Coll et al. 2012, 2015, Piante \& Ody 2015). In the NW Mediterranean Sea, sea surface temperatures and primary production follow annual cycles characterized by strong seasonality. Although the coastal zones of the area are considered oligotrophic, inputs from the Ebro outflow and episodes of strong winds increase the availability of nutrients. During fall and winter, the water temperature is at its lowest and water column mixing is induced by strong winds, leading to higher nutrient availability at the surface, with a peak of phytoplankton in late winter and spring (Salat et al. 2002). On the other hand, in late spring and summer, during the period of water column stratification, there is a reduction in nutrients in the photic zone. At this

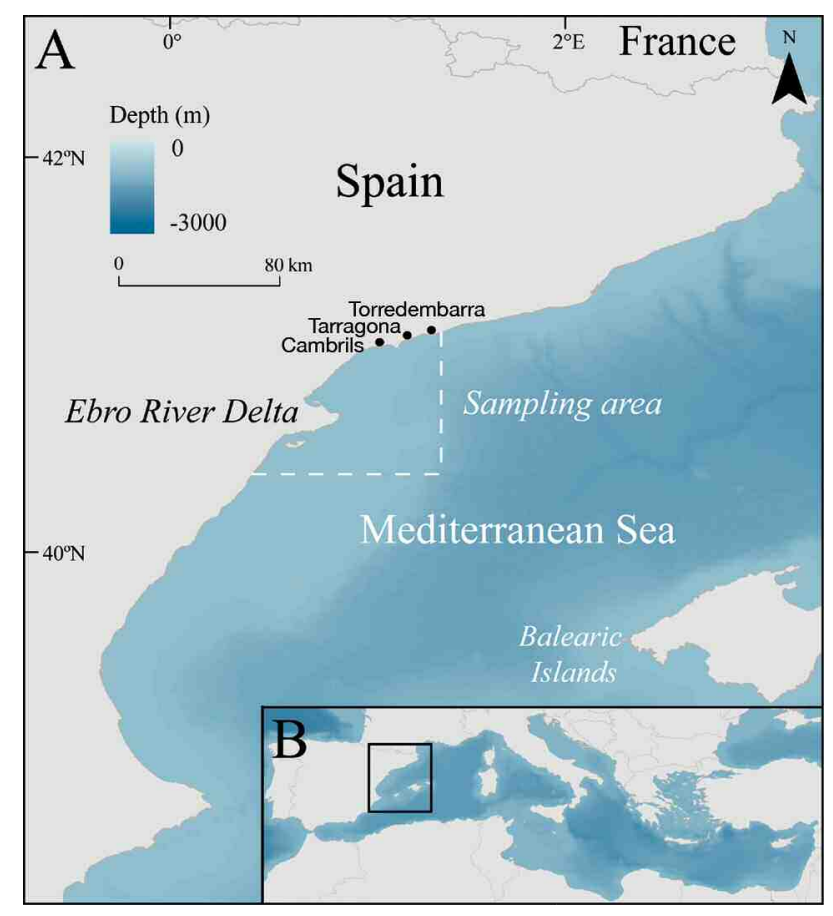

Fig. 1. (A) Sampling area (dashed line) in the NW Mediterranean Sea where round sardinella Sardinella aurita, sardine Sardina pilchardus and anchovy Engraulis encrasicolus were collected. The harbours where samples were landed (Torredembarra, Tarragona and Cambrils) are indicated. (B) Location of the study area in the Mediterranean Sea 
time, the inputs of nutrients to the surface are supplied by the Ebro River outflow (Estrada 1996, Palomera et al. 2007). Zooplankton abundance and composition show high spatial and temporal variability in the NW Mediterranean Sea (Calbet et al. 2001). However, some studies have found higher zooplankton biomass after the late winter/early spring phytoplankton bloom (Andreu \& Duarte 1996, Fernández de Puelles et al. 2003). In general, copepods dominate the zooplankton community throughout the year, with a dominance of calanoid copepods during spring and winter (Calbet et al. 2001, Sabatés et al. 2007). In contrast, other groups present a clear pattern of seasonality. Cladocera and Appendicularia show high abundance in summer and Chaetognatha have a summer-autumn peak, whereas Cnidaria and Thaliacea are abundant in spring (Gili et al. 1988, Calbet et al. 2001, Pascual 2016).

For stomach content analysis, samples of adults and juveniles of round sardinella were obtained from commercial vessels working in the study area (spring 2012 [April and May], winter 2013 [March]) and from an experimental oceanographic cruise carried out in the same study area in summer 2013 (July) (ECOTRANS Project, Institut de Ciències del Mar-CSIC; Fig. 1, Table 2). Samples obtained from commercial vessels, corresponding to spring 2012 and winter 2013, were also used for stable isotope analysis (see Section 2.3). Samples from the experimental oceanographic cruise in summer 2013 were only used for stomach content analysis.
For stable isotope analysis, samples of adults and juveniles of round sardinella, sardine and anchovy were obtained from commercial vessels working in the study area in spring, summer and fall 2012 and winter 2013. All individuals were immediately frozen after capture and stored at $-20^{\circ} \mathrm{C}$ until morphological measurements, tissue and stomach collection were conducted. Total body length ranges considered to classify the individuals as adults or juveniles were based on the size at first maturity (when $50 \%$ of individuals at that size are mature), which was defined as $15 \mathrm{~cm}$ for round sardinella (Tsikliras \& Antonopoulou 2006), $11 \mathrm{~cm}$ for anchovy (Palomera et al. 2003) and $13 \mathrm{~cm}$ for sardine (Abad \& Giraldez 1983).

Several factors can contribute to variation in isotopic signatures and stomach content analysis. It is important to take into account the limitations of both 8echniques (Boecklen et al. 2011, Nielsen et al. 2017). Stomach content analysis provides information on diet over a short period of time (e.g. 1 d), but at a high taxonomic resolution. On the other hand, stable isotopes of muscle tissue integrate the diet of a consumer over a long period (from several weeks to some months in marine fish; Vander Zanden et al. 2015). Values of stable isotope are mostly affected when changes in environmental conditions are persistent in time (seasonal differences) or space (spatial differences) (Boecklen et al. 2011). Therefore, in this study, stable isotope values of summer 2012 are assumed to be representative of summer season for other years (e.g. summer 2013) in the same sampling area.

Table 2. Sampling information of round sardinella Sardinella aurita collected for dietary analysis. Vacuity index (V\%) is the percentage of empty stomachs. Time fished is the typical fishing time range per vessel according to fishing gear

\begin{tabular}{|c|c|c|c|c|c|c|c|}
\hline Season & $\begin{array}{l}\text { Size class } \\
\text { range }(\mathrm{cm})\end{array}$ & $\begin{array}{l}\text { Samples } \\
\text { pooled }\end{array}$ & $\begin{array}{l}\text { No. stomachs } \\
\text { analysed }\end{array}$ & $\mathrm{V} \%$ & $\begin{array}{l}\text { Sampling date } \\
\text { (d/mo/yr) }\end{array}$ & $\begin{array}{l}\text { Time fished } \\
\text { GMT (h) }\end{array}$ & Fishing gear \\
\hline \multicolumn{8}{|c|}{ Spring 2012} \\
\hline & $9.6-13.6$ & No & 20 & 40 & 13/04/12 & 00:00-06:00 & Purse seine \\
\hline & $19.8-25.2$ & No & 10 & 20 & 23/04/12 & 10:00-04:00 & Gillnet \\
\hline & 19-26 & No & 20 & 0 & $04 / 05 / 12$ & 00:00-06:00 & Purse seine \\
\hline \multicolumn{8}{|c|}{ Winter 2013} \\
\hline & $10.8-11.9$ & Yes & 10 & 0 & $26 / 03 / 13$ & $10: 00-04: 00$ & Gillnet \\
\hline & $12.0-13.0$ & Yes & 10 & 0 & $26 / 03 / 13$ & $10: 00-04: 00$ & Gillnet \\
\hline & $13.2-14.7$ & Yes & 10 & 0 & $26 / 03 / 13$ & $10: 00-04: 00$ & Gillnet \\
\hline & $22.2-24.0$ & Yes & 5 & 0 & $20 / 03 / 13$ & 00:00-06:00 & Purse seine \\
\hline \multicolumn{8}{|c|}{ Summer 2013} \\
\hline & $12-16.2$ & Yes & 13 & 0 & $10 / 07 / 13$ & 06:00-07:00 & Bottom trawling \\
\hline & $16.8-23.6$ & Yes & 13 & 7.7 & $10 / 07 / 13$ & $06: 00-07: 00$ & Bottom trawling \\
\hline & $21.5-29.5$ & Yes & 7 & 28.6 & 07/07/13 & $06: 00-07: 00$ & Bottom trawling \\
\hline & $17.5-24.6$ & Yes & 9 & 0 & 07/07/13 & 09:00-10:00 & Bottom trawling \\
\hline & $16.7-20.1$ & Yes & 10 & 0 & 08/07/13 & $11: 00-12: 00$ & Bottom trawling \\
\hline
\end{tabular}




\subsection{Stomach content analysis of round sardinella}

In total, 137 stomachs of round sardinella caught in spring 2012, winter 2013 and summer 2013 were analysed. The stomach contents were extracted under a stereomicroscope (Leica M205 C) and preserved individually in a buffered $5 \%$ formaldehyde-seawater solution. No regurgitation was detected in the oesophagus, and the contents of the intestine were discarded. After disaggregation of stomach contents, pools of 5 to 13 stomachs were diluted to a known volume of filtered seawater, and homogenized aliquots of each pool were examined under a stereomicroscope at 100× magnification until no new prey items were found. Pooling of the stomach contents of fish from the same haul in dietary studies of small pelagic fish is a common practice, since individuals from the same haul present similar prey items in the stomachs (Van Der Lingen 2002, Nikolioudakis et al. 2012). In this study, to pool the stomachs, factors such as size, haul and fishing day were taken into account. Aliquots of 4-7 $\mathrm{ml}$ of the total volume of the pools $(140 \mathrm{ml})$ were analysed. Stomach contents obtained in spring 2012 were not pooled since it was not possible to homogenize the predominant food items; therefore, all stomach contents were individually analysed (Table 2). All prey in the aliquots were identified to the lowest taxonomical level possible (generally up to species or genus level) and counted. Only prey items that could be identified were recorded, and the numbers of identified prey in the pool were standardized to numbers of prey per stomach.

Whenever possible, the length of each prey was measured using an ocular micrometer. Dry weight of prey was mathematically reconstructed from the literature using length-weight relationships for specific species, genera or groups (Borme et al. 2009, Costalago et al. 2012, Brosset et al. 2016; Table S1 in the Supplement at www.int-res.com/ articles/suppl/m620p139_supp.pdf). The contribution in terms of weight of dinoflagellates, tintinnids and diatoms was not considered because of their low weight compared to metazoan prey. Numerical size-frequency histograms of the prey were constructed for each season and each ontogenetic group.

To describe the contribution of each prey group to the diet, the numerical percentage $(\% \mathrm{~N} i=\mathrm{con}-$ tribution by number of food type $i$ in relation to the number of items in the whole contents) and the weight percentage $(\% \mathrm{Wi}=$ dry weight of food type $i$ in relation to the weight of the whole stomach contents) were calculated. All of these trophic metrics were based on the number of non-empty stomachs.

\subsection{Stable isotope analysis}

Stable isotopes of $\delta^{15} \mathrm{~N}$ and $\delta^{13} \mathrm{C}$ have been broadly used to study trophic ecology of consumers (Layman et al. 2012). Particularly, $\delta^{13} \mathrm{C}$ is often used as a proxy of the primary source of dietary carbon and $\delta^{15} \mathrm{~N}$ as a proxy of trophic position (Layman et al. 2012). In the present study, we analysed $\delta^{15} \mathrm{~N}$ and $\delta^{13} \mathrm{C}$ values in muscle samples of round sardinella, anchovy and sardine caught in spring, summer and fall of 2012 and winter 2013. Specifically, a small portion of the dorsal muscle without skin from each fish was sampled, freeze-dried and powdered, and $0.28-0.33 \mathrm{mg}$ of powdered muscle was packed into tin capsules. Isotopic analyses were performed at the Laboratory of Stable Isotopes of the Estación Biológica de Doñana (www.ebd. csic.es/lie/index.html). Samples were combusted at $1020^{\circ} \mathrm{C}$ using a continuous flow isotope-ratio mass spectrometry system (Thermo Electron) by means of a Flash HT Plus elemental analyser interfaced with a Delta V Advantage mass spectrometer. Based on laboratory standards, the measurement error was \pm 0.1 and \pm 0.2 for $\delta^{13} \mathrm{C}$ and $\delta^{15} \mathrm{~N}$, respectively. The standards used were EBD-23 (cow horn, internal standard), LIE-BB (whale baleen, internal standard) and LIE-PA (feathers of razorbill, internal standard). These laboratory standards were previously calibrated with international standards supplied by the International Atomic Energy Agency (Vienna). Correction for lipids was not conducted, since the $\mathrm{C}: \mathrm{N}$ ratio was $<3.5$ for all samples (Post et al. 2007).

To provide insight into species' trophic niche widths, and to estimate the degree of isotopic niche overlap between species, we calculated Bayesian isotopic standard ellipse areas corrected for sample size (SEAc), firstly for each season and then for all seasons together (Jackson et al. 2011). Higher values of this metric represent a broader trophic niche width (Layman et al. 2012). Isotopic SEAs and their overlap were calculated using the routine Stable Isotope Bayesian Ellipses in the SIAR library (SIBER; Jackson et al. 2011). 


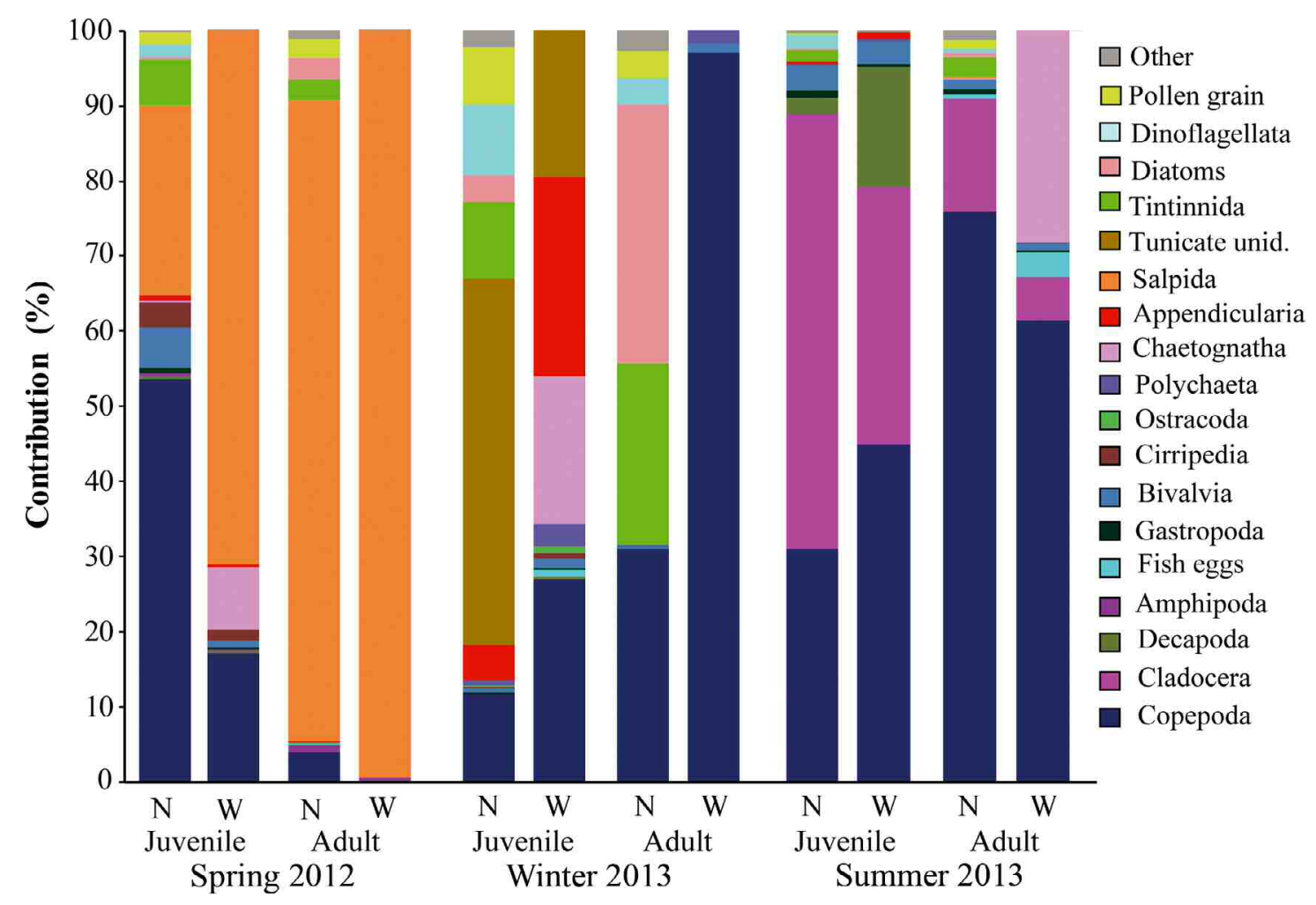

Fig. 2. Percentages of prey categories found in the stomach contents of round sardinella Sardinella aurita juveniles and adults by season (spring 2012, winter 2013 and summer 2013) in terms of number of prey items (N) and weight of prey items (W)

\subsection{Statistical analyses}

Differences in stomach contents of round sardinella between seasons and ontogenetic stages (juveniles and adults) were statistically compared using 2-way semi-parametric permutational multivariate analyses of variance (PERMANOVAs) based on a Bray-Curtis distance matrix (Anderson et al. 2008). Prior to these analyses, data were square-root transformed to minimize the impact of outliers. In the case of significant results, pairwise tests were performed. To analyse the average dissimilarity between seasons and to identify which prey made the greatest contribution to the observed differences in diet composition of adults and juveniles of round sardinella, the SIMPER analysis was applied (Clarke \& Gorley 2006).

Differences in $\delta^{15} \mathrm{~N}$ and $\delta^{13} \mathrm{C}$ values between round sardinella, anchovy and sardine were tested using a 1-way semi-parametric PERMANOVA based on a Euclidean distance matrix (Anderson et al. 2008). Analyses were run using PRIMER-E 6 software (Clarke \& Gorley 2006).

Potential ontogenetic changes in each species were explored by analysing the relationship between iso- topic values and body size (total length) using linear regressions and adopting a significance level of $\alpha=$ 0.05 . Linear regression analyses were performed with R version 3.3.2. (R Core Team, 2018).

\section{RESULTS}

\subsection{Stomach contents of round sardinella}

Overall, the stomach contents of round sardinella were composed of a wide variety of planktonic organisms (58 different prey categories were identified), composed mainly of zooplanktonic organisms (Fig. 2, Table S2). We found significant differences in stomach content composition between seasons and between juvenile and adult stages (Fig. 2; seasons, pseudo- $F_{2,118}=70.30, \mathrm{p}<0.0001 ;$ ontogenetic, pseudo- $F_{1,118}=22.74, \mathrm{p}<0.0001$; all pairwise tests, $\mathrm{p}<0.001$ ). In spring 2012, salps dominated the diet of round sardinella $(\mathrm{N} \%=25.16$ and $85.11 \%$, for juveniles and adults, respectively; $\mathrm{W} \%=70.96$ and $99.20 \%$ for juveniles and adults, respectively; Fig. 3A,B). In addition, amphipods of the suborder 


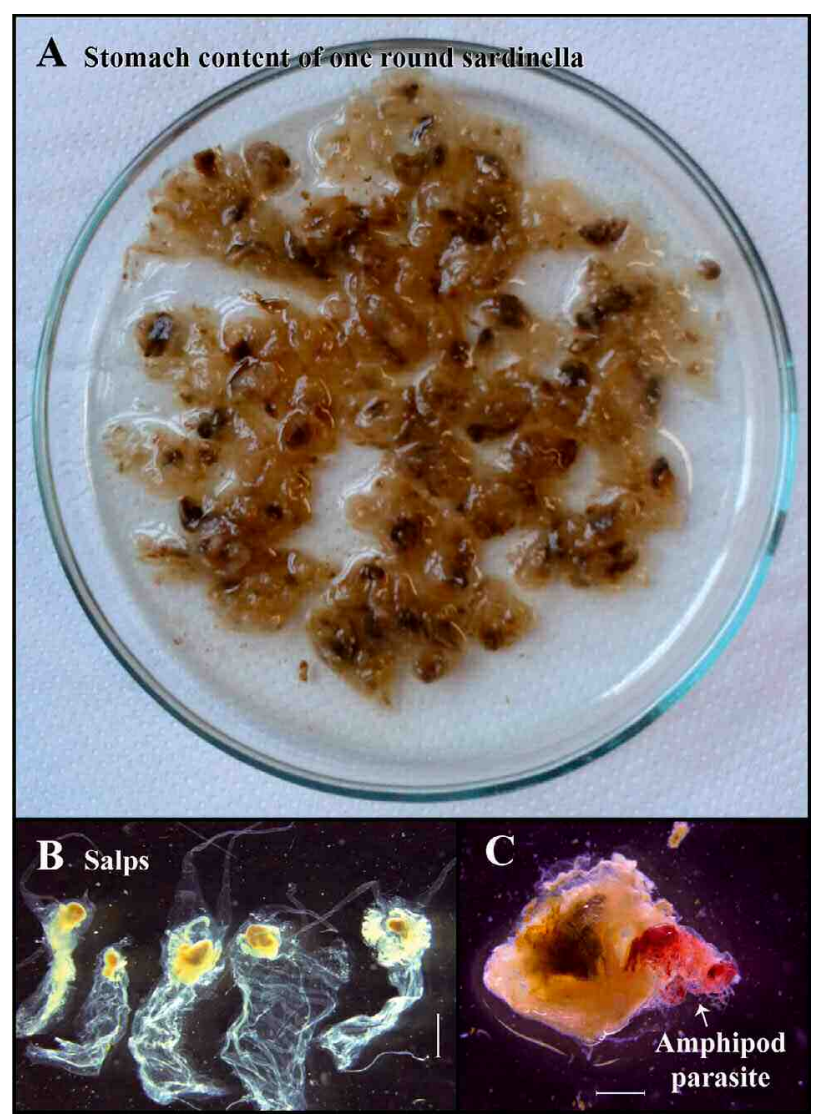

Fig. 3. Prey found in stomachs of round sardinella Sardinella aurita during spring: (A) Petri dish with the contents of 1 stomach, (B) salps isolated from the gut content, (C) specimen of salp with an amphipod parasite. Scale bars are $2 \mathrm{~mm}$

Hyperiidea (Fig. 3C) were present in $68 \%$ of the stomachs of adults, although they were never abundant $(\mathrm{N} \%=0.92 ;$ Fig. 2). In spring, in juveniles of round sardinella, copepods were numerically the most important group ( $\mathrm{N}=53.77 \%$; Table S2), with Centropages spp. and Euterpina acutifrons representing $12 \%$ of total prey number.

During winter 2013, the diet of juveniles and adults was also significantly different (pairwise test, p < 0.001). The diet of juveniles in winter was mainly composed of appendicularians and other unidentified tunicates that numerically represented $26.65 \%$ of the total contents and $45.91 \%$ in dry weight. Moreover, microplankton (diatoms, dinoflagellates and tintinnids) and copepods also made an important contribution to the total diet $(\mathrm{N} \%=31.88$ and $21.79 \%$, respectively). On the other hand, adults of round sardinella preyed mainly on copepods, tintinnids and diatoms $(\mathrm{N} \%=31.08,4.81$ and $34.59 \%$, respectively), but in terms of weight, copepods dom- inated the diet by far (W\% = 97.13\%). Specifically, Acartia spp. and E. acutifrons were the most important copepods.

In summer 2013, the most important prey were copepods $(\mathrm{N} \%=53.56 \%, \mathrm{~W} \%=53.26 \%)$, mainly calanoids, with a higher numerical presence of Acartia spp. in adults and Centropages spp. in juveniles. Cladocerans (mainly Penilia avirostris) were abundant in both ontogenetic stages (Fig. 2). Decapods and chaetognaths were not numerically abundant but were important in terms of dry weight; decapods contributed to $15.92 \%$ of the total diet of juveniles and chaetognaths to $28.13 \%$ of the total diet of adults (Table S2).

Round sardinella consumed prey within a wide size spectrum throughout the year (Fig. 4). In general, juveniles consumed prey of smaller size than adults. In spring 2012, due to the consumption of salps, the range of prey length was very wide, with individuals from $0.1 \mathrm{~mm}$ to $20 \mathrm{~mm}$ (Fig. 4A,B). Prey of size classes $0.1-0.2,0.7-0.8$ and $2.6-2.7 \mathrm{~mm}$ were the most frequently consumed by juveniles, while adults showed preferences for larger prey within the 2.7-2.8, 3.33.4 and $6-7 \mathrm{~mm}$ size class ranges. In winter 2013, due to the high presence of phytoplankton and tintinnids in the stomachs, a high proportion of the prey had a size range $<0.1 \mathrm{~mm}(46.56 \%$ of the total prey measured) (Fig. 4C), while $20.3 \%$ of prey were within 0.4-0.5 mm). In summer 2013, there was a clear difference in size range between adults and juveniles (Fig. 4D). Prey items of $0.2-0.4 \mathrm{~mm}$ contributed $27.12 \%$ to the total measured prey in the diet of round sardinella juveniles, whereas in adults, prey items within the $0.6-0.9 \mathrm{~mm}$ size class contributed $43.60 \%$ to the total measured prey.

Based on numerical composition, SIMPER analysis revealed that the average dissimilarity was high between seasons. The group that contributed more than $10 \%$ to the dissimilarity of the diet between spring 2012 and winter 2013 were diatoms, followed by tintinnids and dinoflagellates $(9.49$ and $8.73 \%$, respectively) and copepods (7.41\%; Table S3), which presented high abundances in winter, while salps that were the most abundant group in spring 2012 made a small contribution to the dissimilarity of diets due to their lower abundance in absolute terms. Comparing spring 2012 and summer 2013 diets, copepods and cladocerans (15.74 and $10.49 \%$, respectively) were the prey groups that contributed most to the dissimilarity between seasons. Cladocerans also highly contributed to the dissimilarity of diets between winter and summer 2013 (13.10\%), followed by diatoms $(9.37 \%)$ and tintinnids (7.55\%; Table S3). 


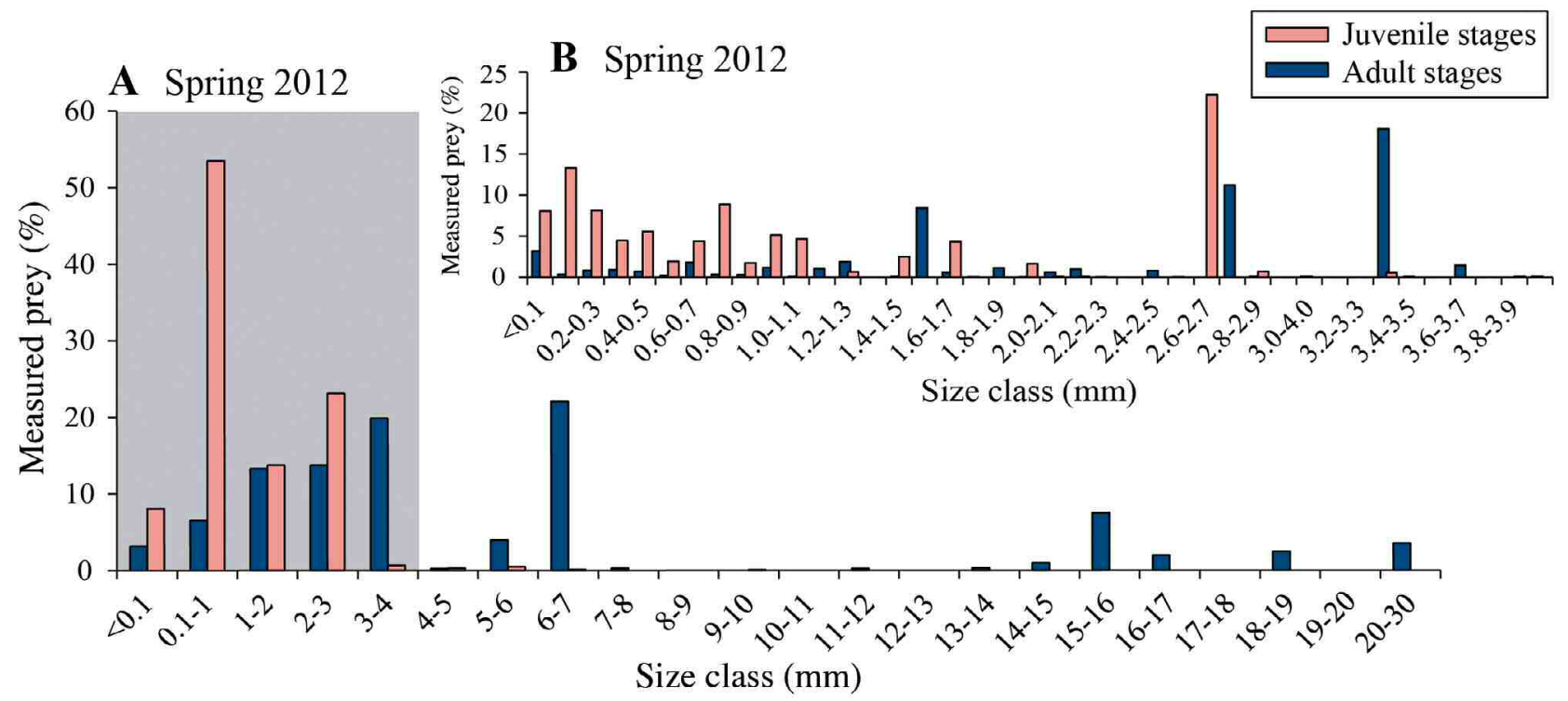

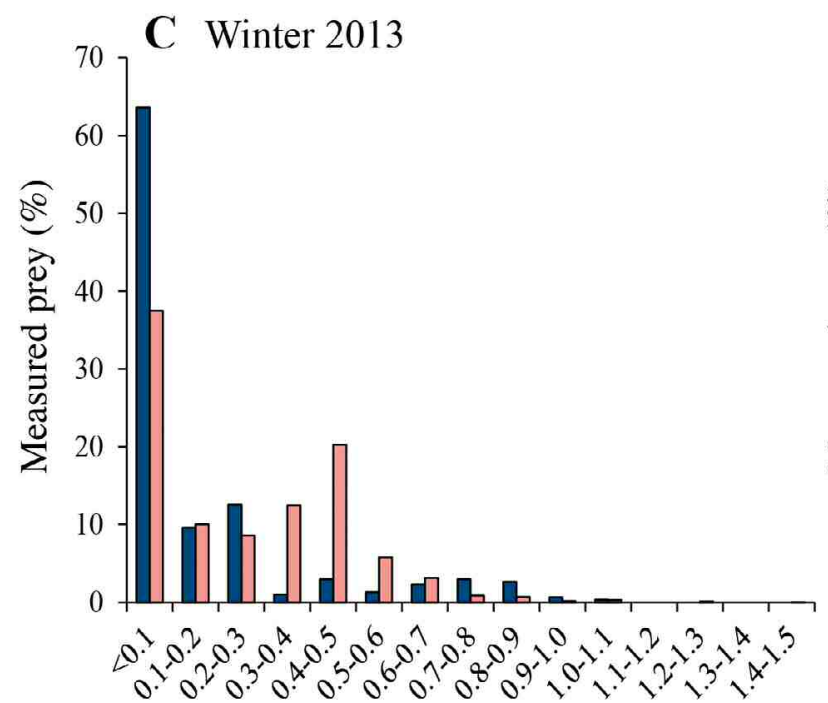

Size class $(\mathrm{mm})$

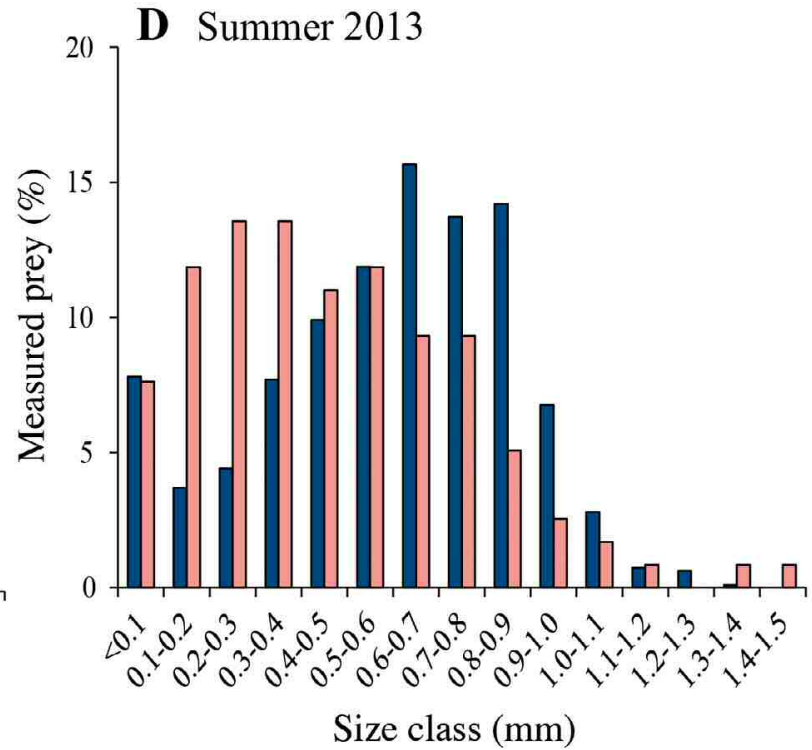

Size class $(\mathrm{mm})$

Fig. 4. Proportion of the prey size classes in the stomach contents of round sardinella by season: (A,B) spring 2012, (C) winter 2013, (D) summer 2013. The shaded range from $<0.1$ to $4 \mathrm{~mm}$ in panel (A) is amplified to a higher resolution in panel (B)

\subsection{Isotopic comparisons among species and sizes}

Stable isotopic values of round sardinella differed significantly from those of anchovy and sardine (Fig. 5 ; pseudo- $F_{2,231}=23.19, \mathrm{p}<0.001$ ). Pairwise tests indicated that, depending on the season, $\delta^{15} \mathrm{~N}$ and $\delta^{13} \mathrm{C}$ values of round sardinella juveniles were similar to anchovy and sardine juveniles. Specifically, when comparing only between juvenile stages of round sardinella and the other 2 species, round sardinella had similar $\delta^{15} \mathrm{~N}$ and $\delta^{13} \mathrm{C}$ with sardine in summer 2012 and anchovy in fall 2012 (Table 3). In winter 2013 , round sardinella juveniles had $\delta^{15} \mathrm{~N}$ and $\delta^{13} \mathrm{C}$ values similar to both sardine and anchovy juveniles. In contrast, comparison between adult stages revealed that round sardinella adults had significantly higher $\delta^{15} \mathrm{~N}$ and $\delta^{13} \mathrm{C}$ values than anchovy and sardine adults during the different seasons (pairwise comparison $\mathrm{p}<0.001$; Table 3 ).

SEAc values (a proxy of trophic niche) of round sardinella overlapped differently with anchovy and sardine depending on the ontogenetic stage and season. In spring 2012, round sardinella juveniles showed little overlap with sardine juveniles $(3.47 \%)$. Round sardinella adults also overlapped with sardine juveniles (9.84\%; Fig. 5). In summer 2012, round sar- 


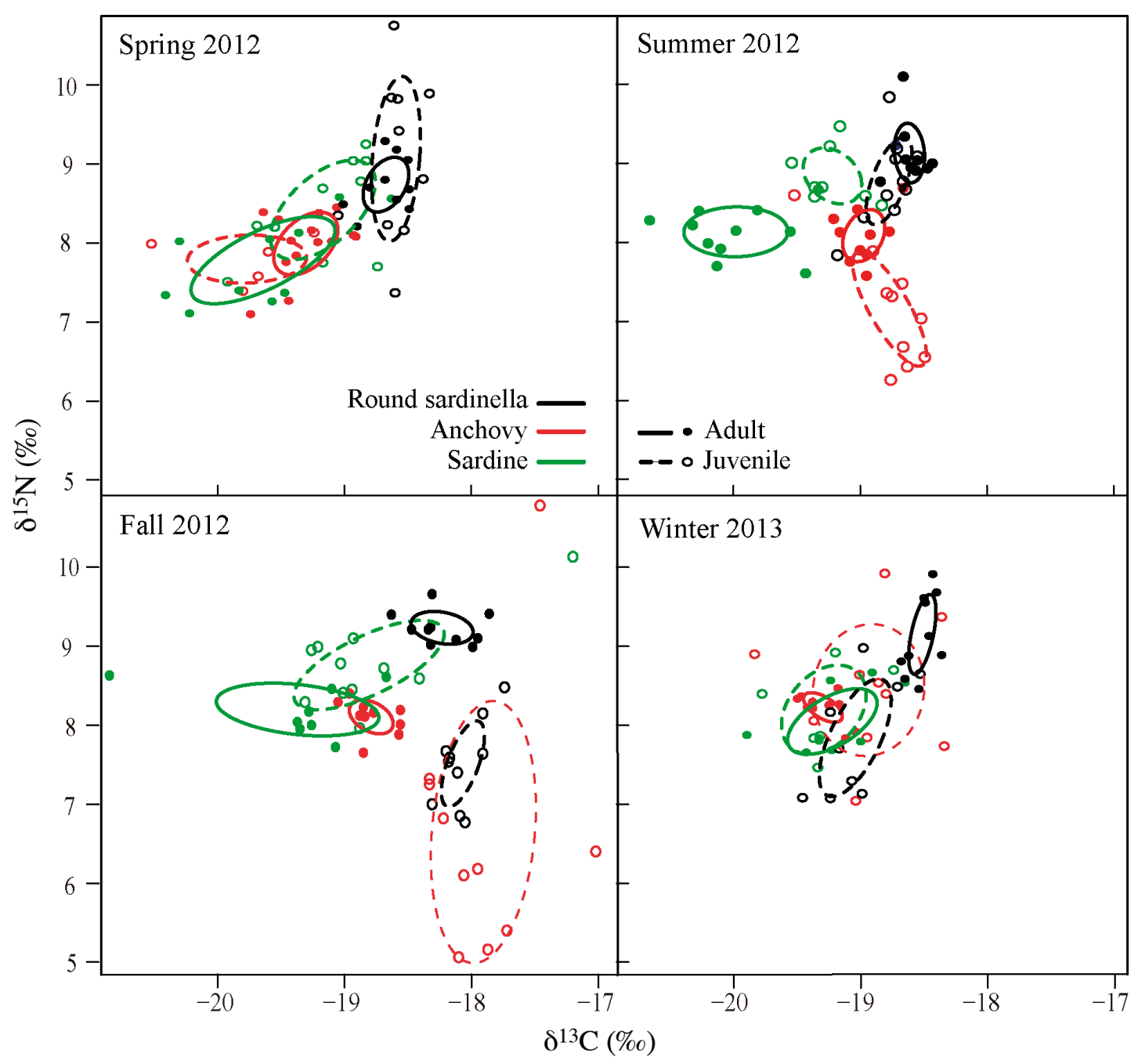

Fig. 5. Standard ellipses for adults (solid lines) and juveniles (dashed lines) of round sardinella Sardinella aurita, anchovy Engraulis encrasicolus and sardine Sardina pilchardus during spring, summer, fall 2012 and winter 2013. Individual $\delta^{15} \mathrm{~N}$ and $\delta^{13} \mathrm{C}$ values of adults (filled dots) and juveniles (open dots) are also graphed

dinella juveniles overlapped with anchovy adults $(17.02 \%)$, while round sardinella adults segregated completely from the other 2 species. In fall 2012 and winter 2013, there was greater SEAc overlap between round sardinella and the other 2 small pelagic fish. In fall 2012, the overlap of round sardinella juveniles with anchovy juveniles was $18.87 \%$, while round sardinella adults overlapped with sardine juveniles (14.85\%; Fig. 5). In winter 2013, round sardinella juveniles had an overlap of 26.74 and $39.19 \%$ with sardine juveniles and adults, respectively, and an overlap between round sardinella juveniles and anchovy adults and juveniles of 41.29 and $2.46 \%$, respectively. In contrast, round sardinella adults only overlapped the isotopic niche with anchovy juveniles in a low proportion (5.77\%; Fig. 5).
When assessing all seasons together and the SEAc as a measure of trophic niche width, we observed that round sardinella juveniles had a wider trophic niche width than adults (Fig. 6). Therefore, round sardinella juveniles overlapped in high proportion with anchovy juveniles $(40.9 \%)$, which also present a large trophic niche width, and with sardine juveniles (25.83\%; Fig. 6). In contrast, the SEAc of round sardinella juveniles overlapped in low proportion with that of anchovy adults $(9.91 \%)$. The low overlap observed with sardine adults was not considered as a potential trophic overlap between these 2 groups (round sardinella juveniles and sardine adults; $0.03 \%$ ). Round sardinella at adult stages only overlapped with sardine juveniles in low proportion $(8.21 \%)$ and segregated 
Table 3. Number of analysed individuals (n), mean \pm SD of $\delta^{15} \mathrm{~N}$ and $\delta^{13} \mathrm{C}$ values (in \%) and total body length (TL \pm SD; in $\mathrm{cm}$ ) of juveniles and adults of round sardinella Sardinella aurita, anchovy Engraulis encrasicolus and sardine Sardina pilchardus during spring, summer, fall and winter

\begin{tabular}{|c|c|c|c|c|c|c|c|c|}
\hline & \multicolumn{2}{|c|}{ Spring 2012} & \multicolumn{2}{|c|}{ Summer 2012} & \multicolumn{2}{|c|}{ Fall 2012} & \multicolumn{2}{|c|}{ Winter 2013} \\
\hline & Juvenile & Adult & Juvenile & Adult & Juvenile & Adult & Juvenile & Adult \\
\hline \multicolumn{9}{|c|}{ Round sardinella } \\
\hline $\mathrm{n}$ & 10 & 10 & 6 & 14 & 10 & 10 & 9 & 10 \\
\hline$\delta^{15} \mathrm{~N}$ & $9.1 \pm 1.0$ & $8.7 \pm 0.3$ & $8.9 \pm 0.7$ & $9.0 \pm 0.4$ & $7.5 \pm 0.5$ & $9.2 \pm 0.2$ & $7.9 \pm 0.7$ & $9.2 \pm 0.5$ \\
\hline$\delta^{13} \mathrm{C}$ & $-18.6 \pm 0.2$ & $-18.7 \pm 0.2$ & $-18.8 \pm 0.2$ & $-18.7 \pm 0.1$ & $-18.1 \pm 0.2$ & $-18.2 \pm 0.2$ & $-19.0 \pm 0.3$ & $-18.5 \pm 0.1$ \\
\hline $\mathrm{TL}$ & $11.0 \pm 0.7$ & $23.6 \pm 1.5$ & $13.2 \pm 0.6$ & $20.7 \pm 3.5$ & $10.3 \pm 1.4$ & $24.0 \pm 1.8$ & $11.8 \pm 0.8$ & $23.2 \pm 1.1$ \\
\hline \multicolumn{9}{|c|}{ Anchovy } \\
\hline $\mathrm{n}$ & 5 & 14 & 10 & 10 & 10 & 10 & 10 & 11 \\
\hline$\delta^{15} \mathrm{~N}$ & $7.8 \pm 0.3$ & $8.0 \pm 0.4$ & $7.2 \pm 0.7$ & $8.1 \pm 0.3$ & $6.6 \pm 1.7$ & $8.1 \pm 0.2$ & $8.4 \pm 0.8$ & $8.2 \pm 0.2$ \\
\hline$\delta^{13} \mathrm{C}$ & $-19.8 \pm 0.5$ & $-19.3 \pm 0.3$ & $-18.8 \pm 0.3$ & $-19.0 \pm 0.2$ & $-17.9 \pm 0.4$ & $-18.8 \pm 0.2$ & $-18.9 \pm 0.4$ & $-19.3 \pm 0.2$ \\
\hline TL & $10.3 \pm 0.2$ & $13.9 \pm 1.9$ & $8.2 \pm 0.7$ & $14.5 \pm 1.2$ & $8.4 \pm 0.9$ & $14.0 \pm 1.3$ & $9.6 \pm 1.1$ & $14.0 \pm 0.8$ \\
\hline \multicolumn{9}{|c|}{ Sardine } \\
\hline $\mathrm{n}$ & 10 & 10 & 8 & 11 & 11 & 8 & 6 & 9 \\
\hline$\delta^{15} \mathrm{~N}$ & $8.4 \pm 0.6$ & $7.8 \pm 0.6$ & $8.8 \pm 0.4$ & $8.1 \pm 0.3$ & $8.8 \pm 0.6$ & $8.2 \pm 0.3$ & $8.2 \pm 0.6$ & $8.1 \pm 0.4$ \\
\hline$\delta^{13} \mathrm{C}$ & $-19.2 \pm 0.4$ & $-19.6 \pm 0.6$ & $-19.2 \pm 0.2$ & $-20.0 \pm 0.4$ & $-18.8 \pm 0.6$ & $-19.4 \pm 0.6$ & $-19.3 \pm 0.3$ & $-19.2 \pm 0.4$ \\
\hline TL & $11.3 \pm 0.2$ & $17.9 \pm 0.6$ & $9.5 \pm 0.3$ & $15.7 \pm 1.2$ & $10.6 \pm 0.6$ & $17.7 \pm 1.0$ & $11.5 \pm 0.2$ & $12.9 \pm 0.5$ \\
\hline
\end{tabular}

the trophic niche from both ontogenetic stages of anchovy (Fig. 6).

Regarding the isotopic niche width, round sardinella and anchovy both showed larger isotopic niche width at the juvenile than at the adult stage. Conversely, sardine had a slightly larger isotopic niche at the adult stage (Fig. 6). These trends were also supported by the relationship between body length and $\delta^{15} \mathrm{~N}$ values (Fig. 7). Body length of anchovy and round sardinella were positively correlated to $\delta^{15} \mathrm{~N}$ values, suggesting a higher trophic position of largersized individuals even when smaller-sized individuals (juveniles) showed high variability in $\delta^{15} \mathrm{~N}$ values (Fig. 7A,B). In contrast, body length and $\delta^{15} \mathrm{~N}$ values of sardine were negatively correlated (Fig. 7C), indicating lower trophic positions of larger-sized

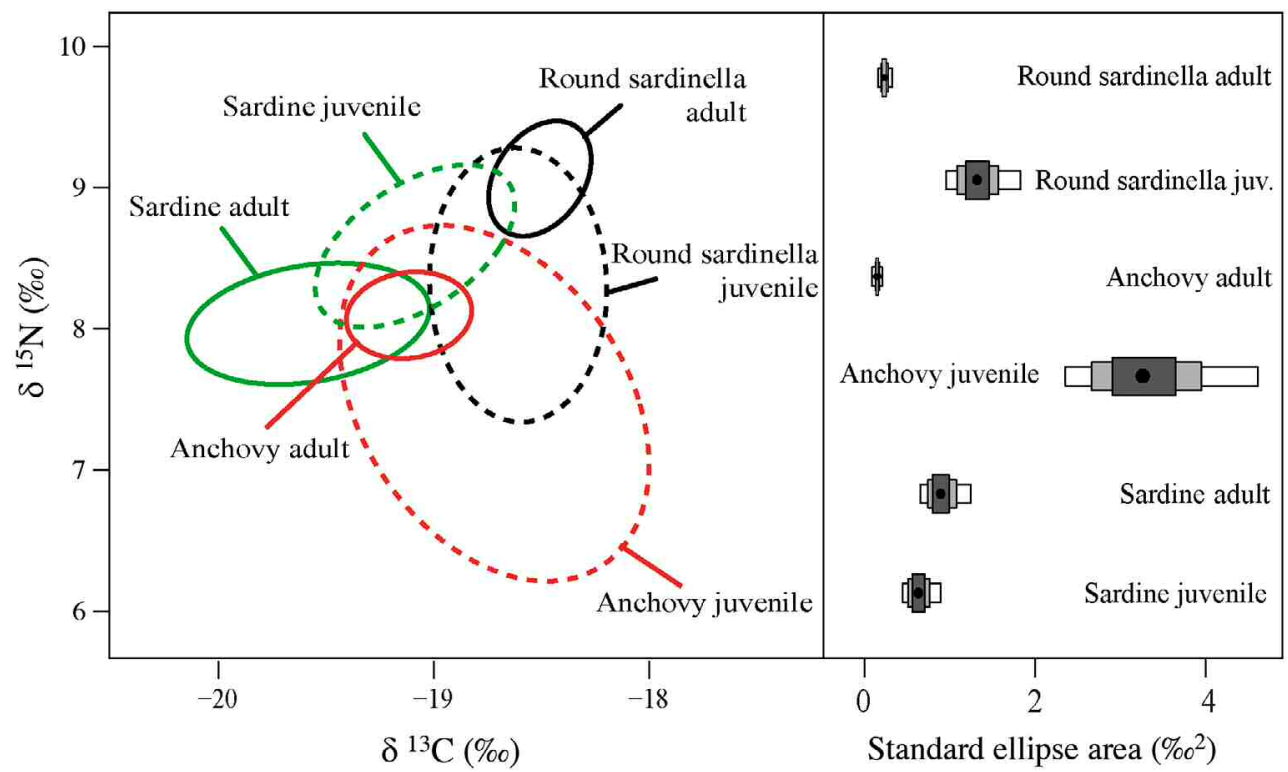

Fig. 6. Isotopic ellipse areas $\left(\delta^{15} \mathrm{~N}\right.$ and $\delta^{13} \mathrm{C}$, in $\left.\%^{2}\right)$ of adults and juveniles of round sardinella Sardinella aurita, anchovy Engraulis encrasicolus and sardine Sardina pilchardus combining isotopic data from all seasons (spring, summer, fall 2012 and winter 2013). The right side shows density plots of Bayesian ellipse area as a proxy of trophic niche width. Black points correspond to the mean standard ellipse area, while boxes show 50 (black), 75 (grey) and 95\% (white) credible intervals 


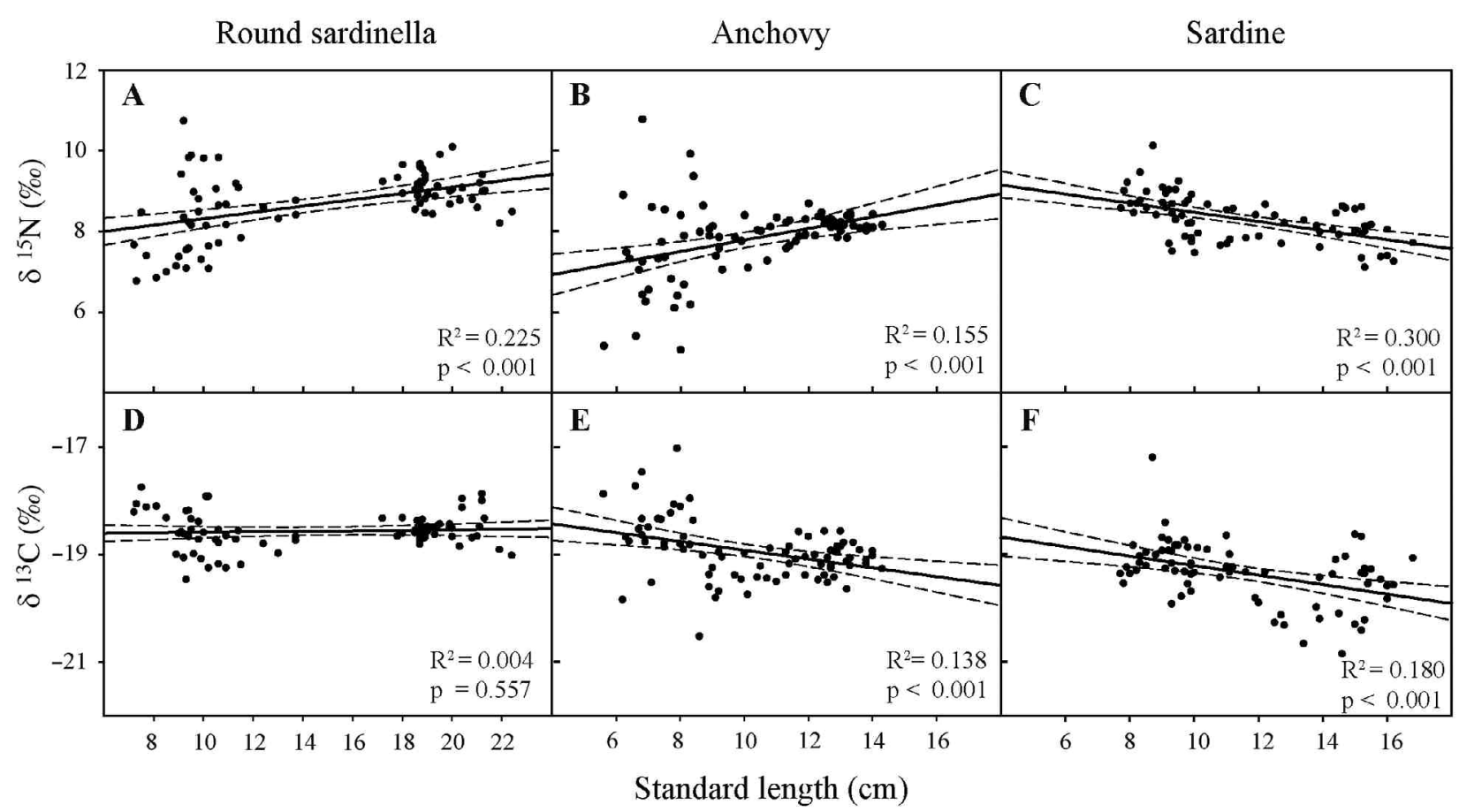

Fig. 7. Relationships between the body length (standard length, in $\mathrm{cm}$ ), $\delta^{15} \mathrm{~N}$ and $\delta^{13} \mathrm{C}$ values of $(\mathrm{A}, \mathrm{D})$ round sardinella Sardinella aurita, $(\mathrm{B}, \mathrm{E})$ anchovy Engraulis encrasicolus and $(\mathrm{C}, \mathrm{F})$ sardine Sardina pilchardus. Solid line: linear regression; dashed line: $95 \%$ confidence interval

sardines. In anchovy and sardine, body length had a significantly negative relationship with $\delta^{13} \mathrm{C}$ (Fig. 7E,F), whereas round sardinella body length and $\delta^{13} \mathrm{C}$ did not show any relationship (Fig. 7D).

\section{DISCUSSION}

In this study, we present new information on the trophic ecology of round sardinella, a rangeexpanding pelagic fish in the NW Mediterranean Sea, by combining stomach content and isotopic analyses. Overall, stomach contents revealed that round sardinella mainly preys on gelatinous zooplankton, copepods, cladocerans, tintinnids and diatoms, indicating a generalist diet. Likewise, isotopic results revealed that round sardinella partially overlaps in its trophic niche with anchovy and sardine, mostly at the juvenile stages, whereas it mostly segregates its trophic niche at the adult stage. The observed seasonal variation in the diet of round sardinella is in accordance with the opportunistic feeding behaviour described for round sardinella in other areas (Cury \& Fontana 1988, Tsikliras et al. 2005). However, to our knowledge, this is the first time that gelatinous zooplankton, mainly salps, have been described as the main prey for round sardinella and other small pelagic fish in the Mediterranean Sea (Karachle \& Stergiou 2017).

Feeding on salps by small pelagic fish has been reported in the southwestern Atlantic Ocean, where the analysis of stomach contents of Argentine anchoveta Engraulis anchoita revealed that this species consumed large quantities of salps when the availability of other zooplankton groups, such as copepods and cladocerans, was lower in the ecosystem (Mianzan et al. 2001). However, because we did not have data on the zooplankton abundance during the fish-sampling period, we cannot establish if round sardinella selected salps over other prey or fed on salps because they were more abundant at the time than other planktonic groups. Salps generally form large swarms (blooms), especially during spring (Pascual 2016), so it is likely that round sardinella prey on salps due to the high availability of this prey in certain periods. Although gelatinous zooplankton has generally been considered a prey of low nutritional quality without relevance for predators (Doyle et al. 2007), in recent years it has been found that salps are more nutritional than previously thought, with a high protein content (Henschke et al. 2016). The energy demand of marine predators may be achieved by a high consumption of salps (Dubischar et al. 2012, Henschke et al. 2016), as has been 
observed for top predators in the NW Mediterranean Sea (Cardona et al. 2012) and similar to what we observed for round sardinella in spring. Moreover, we also found amphipods of the family Hyperiidae in many stomachs of round sardinella, which are common parasites of salps (Laval 1980). The ingestion of these amphipods may increase the energy gain from the consumption of salps. Other tunicates (mainly appendicularians) were an important part of the diet of juvenile round sardinella during winter. This could be related to the large aggregations of this prey that are sometimes found in the western Mediterranean (Champalbert 1996). This result is in agreement with a previous study that observed dietary preference of round sardinella for tunicates during the cold season in the central Mediterranean Sea (Lomiri et al. 2008).

Recently, qualitative ecosystem food-web models representing the NW Mediterranean pelagic ecosystem highlighted the key role of gelatinous zooplankton when describing the temporal dynamics of small pelagic fish (Coll et al. 2019). The ability of round sardinella to eat gelatinous zooplankton compared to other small pelagic species (see Table 1) may represent an advantage in future potential scenarios of global warming (opportunism hypothesis), since gelatinous zooplankton is expected to positively benefit from future environmental changes (Molinero et al. 2009, Brotz \& Pauly 2012, Brotz et al. 2012, Grémillet et al. 2017). Moreover, if round sardinella have the capacity to consume salps and other clupeiforms do not (see Table 1), round sardinella could be in an advantageous fitness position compared to other small pelagic species in future scenarios where plankton biomass could decrease (Chust et al. 2014). Future ecological models should consider gelatinous zooplankton with a higher resolution to better describe the present and future dynamics of the pelagic ecosystems (Jaspers et al. 2014).

The diet of round sardinella was composed of other preferred prey in other seasons. The high proportion of tintinnids and diatoms observed in winter (higher for adults than for juveniles) was probably related to the high abundance of phytoplankton in this season (Arin et al. 2005). In our study area, the increase in phytoplankton biomass is a consequence of the water discharges of the Ebro River and strong northern winds, which may generate local upwelling processes triggering nutrient-enrichment events, which in turn fuel high primary production (Lloret et al. 2004, Arin et al. 2005, Costalago \& Palomera 2014, Barroeta et al. 2017). The presence of phytoplankton in the stomach contents of round sardinella was previously described in areas with upwelling conditions or important inputs of nutrients, such as Senegalese or Egyptian waters (Nieland 1982, Madkour 2012). In contrast, in oligotrophic areas without upwelling events or river discharges, such as the Aegean Sea and the central Mediterranean, the presence of phytoplankton was not reported in the diet of this species (Tsikliras et al. 2005, Lomiri et al. 2008, Karachle \& Stergiou 2014).

Copepods have also been described as the main prey of round sardinella in many studies from the Mediterranean Sea (Tsikliras et al. 2005, Lomiri et al. 2008, Madkour 2012, Karachle \& Stergiou 2014, Bayhan \& Sever 2015). In our study, they were the principal prey (both in number and weight) only during summer, whereas in winter they were the main prey for adults exclusively in terms of weight since phytoplankton was numerically the most abundant prey as mentioned above.

During summer, coinciding with the reproductive season of round sardinella (Palomera et al. 2007), cladocerans were found in high proportions in the stomach contents of both adults and juveniles. Cladocerans are an abundant prey in summer (Calbet et al. 2001) and are probably easily captured by round sardinella. Moreover, compared to winter, adults clearly fed on larger prey, which have higher energy content than smaller prey (Barroeta et al. 2017). This coincides with the higher energy demands for reproduction that round sardinella have in summer (AlboPuigserver et al. 2017). In previous studies, while size-related variations in diet were correlated with morphological changes in gill structure, observed seasonal changes in diet were attributed to prey availability (Lomiri et al. 2008). Thus, the observed seasonal changes in the diet of round sardinella in this study are likely related to food availability. However, further studies combining stomach content and plankton composition are needed to confirm this hypothesis.

In winter, although round sardinella preyed on phytoplankton, similarly to that described for sardine, we found no overlap with sardine in terms of isotopic values. In addition, sardine showed a negative relationship of body length to $\delta^{15} \mathrm{~N}$, which highlights that adults of sardine are feeding at a lower trophic level than juveniles, suggesting an active filter-feeding activity as the individuals become larger (Costalago et al. 2012). In contrast, in round sardinella, this relationship was positive, showing that the importance of phytoplankton for round sardinella decreases as individuals grow in size. The observed feeding differences between juveniles and adults of round sardinella in this study were also 
found in round sardinella in the Aegean Sea, where Tsikliras et al. (2005) observed an increasing trophic level of consumed prey with the increase in fish body size, and explained it as a consequence of the different energy needs at different life stages. Juveniles of round sardinella preyed on smaller-sized prey categories than adults in the central Mediterranean Sea (Lomiri et al. 2008), similar to our results, and were related to the changes in the number and separation of gill rakers (Rincon et al. 1988). Although we found that larger individuals fed on larger prey, smaller individuals also had the capacity to prey on larger animals such as salps. The lower mean values of $\delta^{15} \mathrm{~N}$ of round sardinella adults could be a result of predation on lower trophic level species, such as salps (Cardona et al. 2012).

Our results show that adult individuals of round sardinella seem to segregate their niche from other small pelagic fish. The higher values of $\delta^{15} \mathrm{~N}$ observed in almost all seasons may be related to consumption of bigger prey at higher trophic levels than other small pelagic fish. Anchovy and sardine in the Gulf of Lions in summer consume prey mainly in the 0.2-0.6 mm size class (Le Bourg et al. 2015), while in our study, adult round sardinella consumed mainly 0.5-0.9 mm prey. However, during the juvenile stages, round sardinella partially overlapped with juvenile sardine and anchovy (supporting the 'competition hypothesis' at the juvenile stages), and the size class of prey consumed in summer was similar to that described for sardine and anchovy in the Gulf of Lions (Le Bourg et al. 2015). We can thus hypothesize that in situations of food limitation, juveniles of round sardinella, anchovy and sardine could be competitors. However, the wide diversity of prey and the dominant presence of salps in the diet of round sardinella could be a mechanism to reduce the interspecific trophic competition, thus favouring its coexistence with other sympatric small pelagic species. If round sardinella abundance and northward distribution continue to increase with time, its high trophic plasticity associated with its capacity to consume prey not exploited by similar pelagic species could represent an important advantage for this species in the face of changes in zooplankton composition.

We did not observe changes in $\delta^{13} \mathrm{C}$ values with sardinella body length, indicating no changes in the source of carbon between juveniles and adults. This may be related to the habitat sharing between adults and juveniles and the preference for shallower waters of round sardinella (Schismenou et al. 2008). In contrast, a decline in $\delta^{13} \mathrm{C}$ values with increasing body lengths, found for both sardine and anchovy, indicated an increase in carbon sources of pelagic origin with fish size, which is probably due to an expansion of adult distribution ranges from coastal productive areas to the continental shelf as they grow (Giannoulaki et al. 2011, 2013). However, the potential spatial overlap or segregation of juveniles and adults of round sardinella, anchovy and sardine remains to be quantitatively investigated.

In conclusion, this study confirms the capacity of round sardinella to feed on different prey groups and potentially adapt its diet to environmental prey availability, and highlights the importance of the trophic link between gelatinous plankton and this species. Future feeding ecology studies of clupeiforms in the Mediterranean should focus on detecting potential shifts in diet towards a more gelatinous zooplankton preference, which could lead to important consequences in energy fluxes, as it has been observed in small pelagic fish of the Pacific Ocean (Brodeur et al. 2019). Moreover, prey availability and nutritional quality of prey should be included in future trophic studies of small pelagic fish in order to better understand the advantages or disadvantages of preying on gelatinous zooplankton. Due to the differences found in trophic overlap between adult and juvenile round sardinella with sardine and anchovy, it is advisable to integrate different ontogenetic stages in future assessments in order to capture the different trophic interactions.

Acknowledgements. We thank Alessandra de Olazabal and Alenka Goruppi for their support with the prey identification and Raquel Sáez for support in sampling. We also thank the General Fisheries Commission for the Mediterranean Sea (GFCM) for their financial support to present this work at the International Symposium on drivers of dynamics of small pelagic fish resources. This study was funded by ECOTRANS (CTM2011-26333) and PELWEB (ES-PN-2017-CTM 2017-88939-R) projects. M.A.P. was funded by an FPI grant and a Short-Stay FPI grant (BES-2012-054267; Spanish Government). J.N. was funded by a Ramon y Cajal contract (RYC-2015-17809) of the Spanish Government.

\section{LITERATURE CITED}

Abad R, Giraldez A (1983) Reproduction, condition factor and first maturity size in sardine, Sardina pilchardus (Walb.), off the Malaga coast, Alboran Sea (1989-1992). Bol Inst Esp Oceanogr 8:145-155

Albo-Puigserver M, Navarro J, Coll M, Layman CA, Palomera I (2016) Trophic structure of pelagic species in the northwestern Mediterranean Sea. J Sea Res 117: $27-35$

Albo-Puigserver M, Muñoz A, Navarro J, Coll M, Pethybridge H, Sánchez S, Palomera I (2017) Ecological energetics of forage fish from the Mediterranean Sea: sea- 
sonal dynamics and interspecific differences. Deep Sea Res II 140:74-82

Alheit J, Licandro P, Coombs S, Garcia A and others (2014) Reprint of 'Atlantic Multidecadal Oscillation (AMO) modulates dynamics of small pelagic fishes and ecosystem regime shifts in the eastern North and Central Atlantic.'. J Mar Syst 133:88-102

Anderson M, Gorley R, Clarke K (2008) PERMANOVA for PRIMER: guide to software and statistical methods. PRIMER-E, Plymouth

Andreu P, Duarte CM (1996) Zooplankton seasonality in Blanes Bay (northwest Mediterranean). Publ Espec Inst Esp Oceanogr 22:47-54

Arin L, Estrada M, Salat J, Cruzado A (2005) Spatio-temporal variability of size fractionated phytoplankton on the shelf adjacent to the Ebro river (NW Mediterranean). Cont Shelf Res 25:1081-1095

Barroeta Z, Olivar MP, Palomera I (2017) Energy density of zooplankton and fish larvae in the southern Catalan Sea (NW Mediterranean). J Sea Res 124:1-9

Bayhan B, Sever TM (2015) Feeding of the round sardinella Sardinella aurita Valenciennes, 1847 (Osteichthyes: Clupeidae) in the Turkish Aegean Sea. Int J Fauna Biol Stud $2: 38-42$

Ben-Tuvia A (1960) Synopsis of biological data on Sardinella aurita of the Mediterranean Sea and other waters. FAO Fish Biol Synop 14:287-312

Boecklen WJ, Yarnes CT, Cook BA, James AC (2011) On the use of stable isotopes in trophic ecology. Annu Rev Ecol Evol Syst 42:411-440

Borme D, Tirelli V, Brandt SB, Fonda Umani S, Arneri E (2009) Diet of Engraulis encrasicolus in the northern Adriatic Sea (Mediterranean): ontogenetic changes and feeding selectivity. Mar Ecol Prog Ser 392:193-209

Brodeur RD, Hunsicker ME, Hann A, Miller TW (2019) Effects of warming ocean conditions on feeding ecology of small pelagic fishes in a coastal upwelling ecosystem: a shift to gelatinous food sources. Mar Ecol Prog Ser 617-618:149-163

* Brosset P, Le Bourg B, Costalago D, Bănaru D and others (2016) Linking small pelagic dietary shifts with ecosystem changes in the Gulf of Lions. Mar Ecol Prog Ser 554: 157-171

Brosset P, Fromentin JM, Van Beveren E, Lloret J and others (2017) Spatio-temporal patterns and environmental controls of small pelagic fish body condition from contrasted Mediterranean areas. Prog Oceanogr 151:149-162

Brotz L, Pauly D (2012) Jellyfish populations in the Mediterranean Sea. Acta Adriat 53:213-231

*Brotz L, Cheung WWL, Kleisner K, Pakhomov E, Pauly D (2012) Increasing jellyfish populations: trends in Large Marine Ecosystems. Hydrobiologia 690:3-20

Calbet A, Garrido S, Saiz E, Alcaraz M, Duarte C (2001) Annual zooplankton succession in coastal NW Mediterranean waters: the importance of the smaller size fractions. J Plankton Res 23:319-331

Cardona L, de Quevedo A, Borrell A, Aguilar A (2012) Massive consumption of gelatinous plankton by Mediterranean apex predators. PLOS ONE 7:e31329

Champalbert G (1996) Characteristics of zooplankton standing stock and communities in the Western Mediterranean Sea: relations to hydrology. Sci Mar 60(Suppl 2):97-113

* Chust G, Allen JI, Bopp L, Schrum C and others (2014) Biomass changes and trophic amplification of plankton in a warmer ocean. Glob Change Biol 20:2124-2139
Clarke K, Gorley R (2006) PRIMER v6: user manual/tutorial. PRIMER-E, Plymouth

Coll M, Bellido JM (2019) Evaluation of the population status and specific management alternatives for the small pelagic fish stocks in the Northwestern Mediterranean (SPELMED) - Final Report SC NR 02 - TENDER EASME/ EMFF/2016/32 - SPELMED:85

Coll M, Piroddi C, Albouy C, Ben Rais Lasram F and others (2012) The Mediterranean Sea under siege: spatial overlap between marine biodiversity, cumulative threats and marine reserves. Glob Ecol Biogeogr 21:465-480

* Coll M, Steenbeek J, Ben Rais Lasram F, Mouillot D, Cury P (2015) 'Low-hanging fruit' for conservation of marine vertebrate species at risk in the Mediterranean Sea. Glob Ecol Biogeogr 24:226-239

* Coll M, Albo-Puigserver M, Navarro J, Palomera I, Dambacher JM (2019) Who is to blame? Plausible pressures on small pelagic fish population changes in the northwestern Mediterranean Sea. Mar Ecol Prog Ser 617-618:277-294

* Costalago D, Palomera I (2014) Feeding of European pilchard (Sardina pilchardus) in the northwestern Mediterranean: from late larvae to adults. Sci Mar 78:41-54

* Costalago D, Navarro J, Álvarez-Calleja I, Palomera I (2012) Ontogenetic and seasonal changes in the feeding habits and trophic levels of two small pelagic fish species. Mar Ecol Prog Ser 460:169-181

*ैCostalago D, Palomera I, Tirelli V (2014) Seasonal comparison of the diets of juvenile European anchovy Engraulis encrasicolus and sardine Sardina pilchardus in the Gulf of Lions. J Sea Res 89:64-72

* Cury P, Fontana A (1988) Compétition et stratégies démographiques comparées de deux espèces de sardinelles (Sardinella aurita et Sardinella maderensis) des côtes ouest-africaines. Aquat Living Resour 1:165-180

*Doyle TK, Houghton JDR, McDevitt R, Davenport J, Hays GC (2007) The energy density of jellyfish: estimates from bomb-calorimetry and proximate-composition. J Exp Mar Biol Ecol 343:239-252

* Dubischar CD, Pakhomov EA, von Harbou L, Hunt BPV, Bathmann UV (2012) Salps in the Lazarev Sea, Southern Ocean. II. Biochemical composition and potential prey value. Mar Biol 159:15-24

Estrada M (1996) Primary production in the northwestern Mediterranean. Sci Mar 60:55-64

*Fernández de Puelles ML, Grás D, Hernández-León S (2003) Annual cycle of zooplankton biomass, abundance and species composition in the neritic area of the Balearic Sea, Western Mediterranean. Mar Ecol 24:123-139

* Giannoulaki M, Pyrounaki MM, Liorzou B, Leonori I and others (2011) Habitat suitability modelling for sardine juveniles (Sardina pilchardus) in the Mediterranean Sea. Fish Oceanogr 20:367-382

Giannoulaki M, Iglesias M, Tugores MP, Bonanno A and others (2013) Characterizing the potential habitat of European anchovy Engraulis encrasicolus in the Mediterranean Sea, at different life stages. Fish Oceanogr 22:69-89

Gili JM, Pagés F, Sabatés A, Ros JD (1988) Small-scale distribution of a cnidarian population in the Western Mediterranean. J Plankton Res 10:385-401

* Grémillet D, White CR, Authier M, Dorémus G, Ridoux V, Pettex E (2017) Ocean sunfish as indicators for the 'rise of slime.' Curr Biol 27:R1263-R1264

Henschke N, Everett JD, Richardson AJ, Suthers IM (2016) Rethinking the role of salps in the ocean. Trends Ecol Evol 31:720-733 
Hughes NF, Grand TC (2000) Physiological ecology meets the ideal-free distribution: predicting the distribution of size-structured fish populations across temperature gradients. Environ Biol Fishes 59:285-298

Intxausti L, Villate F, Motos L, Uriarte I, Iriarte A (2017) Diet variability in European anchovy: a comparative analysis between larval populations of the inner Bay of Biscay and the NW Mediterranean. Hydrobiologia 790:49-65

Jackson AL, Inger R, Parnell AC, Bearhop S (2011) Comparing isotopic niche widths among and within communities: SIBER - Stable Isotope Bayesian Ellipses in R. J Anim Ecol 80:595-602

Jaspers C, Acuña JL, Brodeur RD (2014) Interactions of gelatinous zooplankton within marine food webs. J Plankton Res 37:985-988

Karachle PK, Stergiou KI (2014) Feeding and ecomorphology of three clupeoids in the North Aegean Sea. Mediterr Mar Sci 15:9-26

Karachle PK, Stergiou KI (2017) An update on the feeding habits of fish in the Mediterranean Sea (2002-2015). Mediterr Mar Sci 18:43-52

"Last PR, White WT, Gledhill DC, Hobday AJ, Brown R, Edgar GJ, Pecl G (2011) Long-term shifts in abundance and distribution of a temperate fish fauna: a response to climate change and fishing practices. Glob Ecol Biogeogr 20:58-72

Laval P (1980) Hyperiid amphipods as crustacean parasitoids associated with gelatinous zooplankton. Oceanogr Mar Biol Annu Rev 18:11-56

Layman CA, Araujo MS, Boucek R, Hammerschlag-Peyer CM and others (2012) Applying stable isotopes to examine food-web structure: an overview of analytical tools. Biol Rev Camb Philos Soc 87:545-562

Le Bourg B, Bănaru D, Saraux C, Nowaczyk A and others (2015) Trophic niche overlap of sprat and commercial small pelagic teleosts in the Gulf of Lions (NW Mediterranean Sea). J Sea Res 103:138-146

*Lloret J, Palomera I, Salat J, Solé I (2004) Impact of freshwater input and wind on landings of anchovy (Engraulis encrasicolus) and sardine (Sardina pilchardus) in shelf waters surrounding the Ebre (Ebro) River delta (northwestern Mediterranean). Fish Oceanogr 13:102-110

Lomiri S, Scacco U, Mostarda E, Andaloro F (2008) Sizerelated and temporal variation in the diet of the round sardinella, Sardinella aurita (Valenciennes, 1847), in the central Mediterranean Sea. J Appl Ichthyol 24: 539-545

Madin EMP, Ban NC, Doubleday ZA, Holmes TH, Pecl GT, Smith F (2012) Socio-economic and management implications of range-shifting species in marine systems. Glob Environ Change 22:137-146

Madkour FF (2012) Feeding ecology of the round sardinella, Sardinella aurita (Family: Clupeidae) in the Egyptian Mediterranean waters. Int J Environ Sci Eng 2:83-92

Mianzan H, Pájaro M, Alvarez Colombo G, Madirolas A (2001) Feeding on survival-food: gelatinous plankton as a source of food for anchovies. Hydrobiologia 451: 45-53

Molinero JC, Buecher E, Lučić D, Malej A, Miloslavic M (2009) Climate and Mediterranean jellyfish: assessing the effect of temperature regimes on jellyfish outbreak dynamics. Ann Ser Hist Nat 19:1-8

Morote E, Olivar MP, Villate F, Uriarte I (2008) Diet of round sardinella, Sardinella aurita, larvae in relation to plankton availability in the NW Mediterranean. J Plankton Res 30:807-816
Morote E, Olivar MP, Villate F, Uriarte I (2010) A comparison of anchovy (Engraulis encrasicolus) and sardine (Sardina pilchardus) larvae feeding in the Northwest Mediterranean: influence of prey availability and ontogeny. ICES J Mar Sci 67:897-908

Nieland H (1982) The food of Sardinella aurita (Val.) and Sardinella eba (Val.) off of the coast of Senegal. Rapp PV Réun Cons Int Explor Sci Mer 180:369-373

* Nielsen JM, Clare EL, Hayden B, Brett MT, Kratina P (2018) Diet tracing in ecology: method comparison and selection. Methods Ecol Evol 9:278-291

* Nikolioudakis N, Isari S, Pitta P, Somarakis S (2012) Diet of sardine Sardina pilchardus: an 'end-to-end' field study. Mar Ecol Prog Ser 453:173-188

Palomera I, Tejeiro B, Alemany F (2003) Size at first maturity of the NW Mediterranean anchovy. GFCM-SAC SubCommittee Stock Assess Work Gr Small Pelagic Species, March 2003, Tangiers

Palomera I, Olivar MP, Salat J, Sabatés A, Coll M, García A, Morales-Nin B (2007) Small pelagic fish in the NW Mediterranean Sea: an ecological review. Prog Oceanogr 74: 377-396

Pascual M (2016) Spatio-temporal processes explaining salp aggregations and their role the Catalan Sea, Northwestern Mediterranean Sea. PhD dissertation, Universitat Politècnica de Catalunya, Barcelona

Piante C, Ody D (2015) Blue growth in the Mediterranean Sea: the challenge of good environmental status. MedTrends Project, WWF-France,

*Plounevez S, Champalbert G (2000) Diet, feeding behaviour and trophic activity of the anchovy (Engraulis encrasicolus L.) in the Gulf of Lions (Mediterranean Sea). Oceanol Acta 23:175-192

* Post DM, Layman CA, Arrington DA, Takimoto G, Quattrochi J, Montaña CG (2007) Getting to the fat of the matter: models, methods and assumptions for dealing with lipids in stable isotope analyses. Oecologia 152: 179-189

R Core Team (2018) R: a language and environment for statistical computing. R Foundation for Statistical Computing, Vienna

Rincon MC, Huq MF, Ramirez-Arredondo I (1988) Aspectos alimenticios de la sardina, Sardinella aurita Valenciennes, 1847 (Pisces: Clupeidae) de los alrededores de la region noroccidental dela peninsula de Araya y alrededores de las islas de coche y cubagua, Venezuela. Bol Inst Ocean Venez Univ Oriente 27:129-143

Sabatés A, Martín P, Lloret J, Raya V (2006) Sea warming and fish distribution: the case of the small pelagic fish, Sardinella aurita, in the western Mediterranean. Glob Change Biol 12:2209-2219

Sabatés A, Olivar MP, Salat J, Palomera I, Alemany F (2007) Physical and biological processes controlling the distribution of fish larvae in the NW Mediterranean. Prog Oceanogr 74:355-376

Sabatés A, Zaragoza N, Grau C, Salat J (2008) Vertical distribution of early developmental stages in two coexisting clupeoid species, Sardinella aurita and Engraulis encrasicolus. Mar Ecol Prog Ser 364:169-180

*Sabatés A, Salat J, Raya V, Emelianov M, Segura-Noguera M (2009) Spawning environmental conditions of Sardinella aurita at the northern limit of its distribution range, the western Mediterranean. Mar Ecol Prog Ser 385:227-236

S Salat J, Garcia MA, Cruzado A, Palanques A and others 
(2002) Seasonal changes of water mass structure and shelf slope exchanges at the Ebro shelf (NW Mediterranean). Cont Shelf Res 22:327-348

San Sebastián O, Navarro J, Llorente GA, Richter-Boix Á (2015) Trophic strategies of a non-native and a native amphibian species in shared ponds. PLOS ONE 10: e0130549

Schismenou E, Giannoulaki M, Valavanis VD, Somarakis S (2008) Modeling and predicting potential spawning habitat of anchovy (Engraulis encrasicolus) and round sardinella (Sardinella aurita) based on satellite environmental information. Hydrobiologia 612:201-214.

Sorte CJB, Williams SL, Carlton JT (2010) Marine range shifts and species introductions: comparative spread rates and community impacts. Glob Ecol Biogeogr 19:303-316

Sunday JM, Pecl GT, Frusher S, Hobday AJ and others (2015) Species traits and climate velocity explain geographic range shifts in an ocean-warming hotspot. Ecol Lett 18:944-953

Tilman D (2004) Niche tradeoffs, neutrality, and community structure: a stochastic theory of resource competition, invasion, and community assembly. Proc Natl Acad Sci USA 101:10854-10861

Tsikliras AC (2008) Climate-related geographic shift and sudden population increase a small pelagic fish (Sardinella aurita) in the eastern Mediterranean Sea. Mar Biol Res 4:477-481

Tsikliras AC, Antonopoulou E (2006) Reproductive biology

Editorial responsibility: Stephen Wing,

Dunedin, New Zealand of round sardinella (Sardinella aurita) in the north-eastern Mediterranean. Sci Mar 70:281-290

Tsikliras A, Torre M, Stergiou KI (2005) Feeding habits and trophic level of round sardinella (Sardinella aurita) in the northeastern Mediterranean (Aegean Sea, Greece). J Biol Res 3:67-75

*Tudela S, Palomera I (1997) Trophic ecology of the European anchovy Engraulis encrasicolus in the Catalan Sea (northwest Mediterranean). Mar Ecol Prog Ser 160:121-134

* Van Beveren E, Bonhommeau S, Fromentin JM, Bigot JL and others (2014) Rapid changes in growth, condition, size and age of small pelagic fish in the Mediterranean. Mar Biol 161:1809-1822

* Van Der Lingen CD (2002) Diet of sardine Sardinops sagax in the southern Benguela upwelling ecosystem. S Afr J Mar Sci 24:301-316

¿ैV Vander Zanden MJ, Clayton MK, Moody EK, Solomon CT, Weidel BC (2015) Stable isotope turnover and half-life in animal tissues: a literature synthesis. PLOS ONE 10: e0116182

Z Zeeberg JJ, Corten A, Tjoe-Awie P, Coca J, Hamady B (2008) Climate modulates the effects of Sardinella aurita fisheries off Northwest Africa. Fish Res 89:65-75

* Zgozi S, Barra M, Basilone G, Hamza M and others (2018) Habitat suitability modelling for a key small pelagic fish species (Sardinella aurita) in the central Mediterranean sea. Hydrobiologia 821:83-98

Submitted: January 14, 2019; Accepted: April 8, 2019

Proofs received from author(s): June 9, 2019 